\title{
A COMPARISON BETWEEN LONGWAVE RADIATION CODES
}

\author{
A. Plana-Fattori ${ }^{1}$, P. A. F. Kuhn ${ }^{1,2}$ \& J. C. S. Chagas ${ }^{3}$
}

The reliability of two computationally-efficient, simplified radiation codes employed to evaluate the components of the budget of terrestrial radiation is assessed from comparisons with benchmark calculations, performed with higher accuracy by reference codes. A number of approximations about the longwave radiative transfer in the atmosphere was assumed in the conception of both simplified codes. The first one was developed at the Instituto Astronomico e Geofísico da Universidade de São Paulo (Institute of Astronomy and Geophysics, University of São Paulo (IAG-USP; São Paulo, SP); it provides irradiances throughout the atmosphere from radiances integrated over the whole terrestrial spectrum and previously computed by running the version 7 of the Low Resolution Transmittance radiative transfer code (LOWTRAN-7). The second simplified code under consideration is included in the general circulation model developed at the Center for Ocean-Land-Atmosphere Studies (COLA; USA), which runs at the Centro de Previsão do Tempo e Estudos Climáticos (CPTEC; Cachoeira Paulista, SP) for numerical weather forecasting and climate studies. Benchmark calculations employed in this study were obtained by other groups through careful line-by-line spectral integration under hypothetical atmospheric conditions, prescribed in the scope of the program Intercomparison of Radiative Codes used in Climate Models (ICRCCM). Only the effects due to the emission / absorption by water vapor, carbon dioxide and ozone are analyzed. The effects due to the carbon dioxide are well reproduced by the code CPTEC/COLA and, excepting relatively cold atmospheric conditions, by the code developed at IAG-USP. The effects due to the ozone are underestimated by both simplified codes but mainly by the CPTEC/COLA, once the ozone bands situated outside the region 980$1100 \mathrm{~cm}^{-1}$ were neglected in its development. Sensitivity tests concerning the water vapor continuum absorption indicate that its both components ("self", related to the water vapor partial pressure, and "foreign", related to the dry air pressure) must be considered in order to obtain reliable water vapor absorption estimates. Under hypothetical atmospheric conditions and assuming the occurrence of the three main molecular absorbers, downward longwave irradiances at the surface can be systematically underestimated by the code CPTEC/COLA. Future studies must include not only comparisons between results provided by simplified radiation codes and the respective benchmark calculations under many atmospheric profiles obtained from soundings, but also comparisons between these results and measurements obtained with pyrgeometers near the sounding site.

Key words: Radiative transfer; Radiation processes in general circulation models; Atmospheric

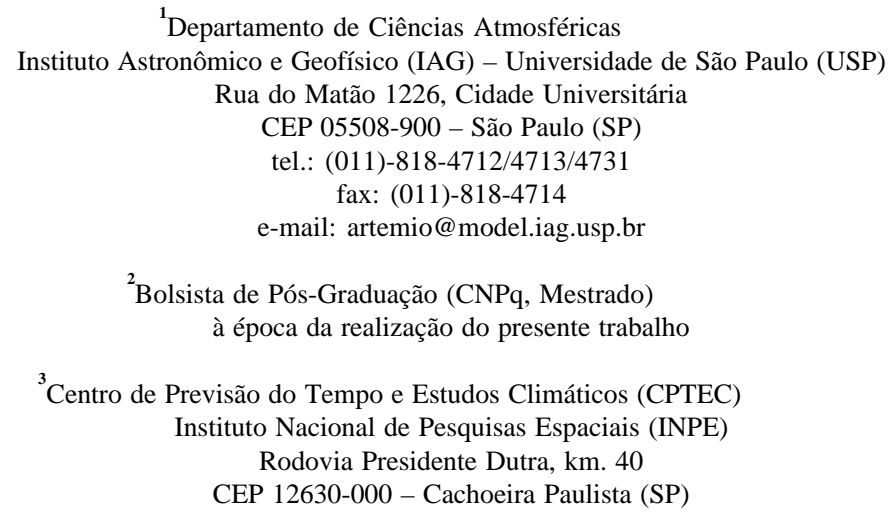




\section{Research Article}

UMA COMPARAÇÃO ENTRE CÓDIGOS RADIATIVOS DE ONDA LONGA- A acurácia de dois algoritmos computacionais (códigos) simplificados para avaliação das componentes do balanço de radiação terrestre (radiação de onda longa), eficientes sob o ponto de vista computacional, é analisada a partir de comparações com cálculos de referência. Os dois códigos foram concebidos a partir de aproximações sobre a transferência de radiação de onda longa na atmosfera. O primeiro deles foi desenvolvido no Instituto Astronômico e Geofísico da Universidade de São Paulo (IAG-USP; São Paulo, SP), fornecendo irradiâncias ao longo da atmosfera a partir das radiâncias integradas sobre todo o espectro terrestre e previamente calculadas pela versão 7 do código de transferência radiativa Low Resolution Transmittance (LOWTRAN-7). O segundo código encontra-se incluído no modelo de circulação geral do Center for Ocean-Land-Atmosphere Studies (COLA; USA) e tem sido empregado no Centro de Previsão do Tempo e Estudos Climáticos do Instituto Nacional de Pesquisas Espaciais (CPTEC/INPE; Cachoeira Paulista, SP). Resultados obtidos com ambos os códigos são comparados com cálculos de referência efetuados respeitando-se a influência de milhares de linhas de absorção associadas aos três compostos moleculares mais relevantes à transferência de radiação de onda longa na atmosfera (vapor d'água, dióxido de carbono e ozônio). Todas as comparações foram efetuadas para condições atmosféricas hipotéticas, sugeridas no âmbito do programa ICRCCM (Intercomparison of Radiative Codes used in Climate Models). Os efeitos associados ao dióxido de carbono são bem reproduzidos pelo código CPTEC/COLA e, a menos de condições atmosféricas relativamente frias, também pelo código desenvolvido no IAG-USP. Os efeitos associados ao ozônio são subestimados por ambos os códigos mas sobretudo pelo CPTEC/ COLA, que não inclui linhas de absorção situadas fora da região $980-1100 \mathrm{~cm}^{-1}$. Testes de sensibilidade realizados sobre os efeitos da absorção continuum associada ao vapor d'água mostram que estes efeitos podem ser bem avaliados desde que sejam consideradas as duas componentes desta absorção (self, dependente da pressão parcial do vapor d'água, e foreign, dependente da pressão do ar seco). Considerando-se condições atmosféricas hipotéticas contendo os três principais absorvedores moleculares, a irradiância descendente à superfície pode ser sistematicamente subestimada pelo código empregado no CPTEC/INPE. Estudos futuros devem avaliar a acurácia absoluta destes (e de outros) códigos, considerando a disponibilidade de medições da irradiância descendente à superfície mediante o emprego de pirgeômetros bem calibrados num sítio onde sejam efetuadas sondagens atmosféricas capazes de fornecer os perfis verticais de temperatura do ar e de concentração dos principais absorvedores.

Palavras-chave: Transferência radiativa; Processos radiativos em modelos de circulação geral; Meteorologia física; Absorção e emissão de radiação; Absorção continuum associada ao vapor d'água; Radiação atmosférica.

\section{INTRODUCTION}

Accurate estimates of the processes involved in the radiative budget are required in general circulation models employed for numerical weather forecasting and climate modeling, as well as in regional models used for analysis of the multiple interactions between the atmosphere and the surface (including the biosphere and the hydrosphere). The role of the radiant energy emitted by the surface and the atmosphere is particularly meaningful once it counterbalances the solar energy absorbed by the planet. As the explicit formulation of the longwave radiative transfer is too complicated for numerical modeling purposes, computationally efficient codes are designed for obtaining irradiances integrated over broad fractions of the terrestrial spectrum. These codes involve relatively simple formulations through which transmittances are associated with absorber contents (water vapor, carbon dioxide, ozone, etc). The simplicity of such codes is illusory, once they allow only the combined effects of thousands of absorption lines, throughout paths with inhomogeneous distributions of absorber concentration, pressure and air temperature. An overview on the subject may be found in some textbooks (e.g., Goody \& Yung, 1989; Liou, 1992) as well as in selected review papers (e.g., Stephens, 1984; Ellingson et al., 1991).

This study summarizes a series of comparisons between results obtained through different approaches for obtaining the longwave components of the radiative budget. The relative reliability of two simplified radiation codes is assessed from comparisons with benchmark calculations provided by other groups. The first code, developed at the Instituto Astronomico e Geofísico da Universidade de São Paulo (Institute of Astronomy and Geophysics, University of São Paulo, IAG-USP, São Paulo, SP) provides irradiances throughout the atmosphere from radiances integrated over the whole 
terrestrial spectrum and previously computed by running the version 7 of the Low Resolution Transmittance radiative transfer code, LOWTRAN-7 (Kneizys et al., 1988). The second code was developed by Harshvardhan et al. (1987); it is employed at the Centro de Previsão do Tempo e Estudos Climáticos, Instituto Nacional de Pesquisas Espaciais (Center for Weather Forecast and Climate Studies, National Institute for Space Research, CPTEC/ INPE, Cachoeira Paulista, SP), running daily for numerical weather forecasting purposes in a version of the general circulation model of the Center for Ocean-LandAtmosphere Studies (COLA, USA; see Sato et al., 1989, for an overview).

The interest on these two simplified radiation codes can be easily justified. Among the codes included in numerical models employed in Brazilian institutions for obtaining weather forecasts, that one developed by Harshvardhan et al. (1987) represents the more detailed description for longwave radiation processes in the atmosphere. Thus, comparisons involving results provided by the code CPTEC/COLA and benchmark calculations could help weather modelers to analyze possible sources of systematic errors (e.g., in forecasting air minimum temperatures). Other codes, like that one proposed by Briegleb (1992), are employed for numerical climate projections only. On the other hand, a large fraction of the Brazilian remote sensing community takes the code LOWTRAN-7 as a tool for estimating atmospheric visible transmittances, forgetting its capabilities in provide firstorder solutions of the radiative transfer equation in the terrestrial wavelength domain - and, therefore, in enable longwave irradiance estimates at the ground and throughout the atmosphere.

In this study, the reliability of both simplified codes is assessed by analyzing the effects due to the emission / absorption by water vapor, carbon dioxide and ozone only. The combination of these effects would describe, in a good first-approximation, the interaction between the longwave radiation and the terrestrial atmosphere under clean (no aerosol) and open-sky (no cloud cover) conditions. The latter are frequently referred as "clear-sky" conditions. Although the effects due to the cloud cover on the radiation budget are qualitatively well-recognized, to evaluate the reliability of simplified radiation codes for estimating these effects is a very difficult task given the near absence of well-documented benchmark calculations. Such an assessment is left for future studies.

The three next sections deal with the benchmark calculations, with the codes IAG-USP and CPTEC/COLA under comparison, and with some aspects involving the water vapor continuum absorption. The last sections discusses the results achieved and presents our recommendation for future studies, respectively. Additional information about the code developed at the IAG-USP has been presented elsewhere (Kuhn, 1997).

\section{BENCHMARK CALCULATIONS}

Under clear-sky conditions, downward $\mathbf{E}^{-}$and upward $\mathbf{E}^{+}$irradiances $\left(\mathrm{W} / \mathrm{m}^{2}\right)$ incident at a given altitude $\mathbf{z}$ and integrated over the whole wavenumber $\mathbf{u}$ domain can be written in the form:

$$
\mathrm{E}^{ \pm}(\mathrm{z})=2 \pi \int_{0}^{1}\left(\int_{0}^{\infty} L(v, \pm \mu, z) d v\right) \mu d \mu,
$$

where $\mathbf{L}(\mathbf{u}, \mathbf{m}, \mathbf{z})$ are spectral radiances $\left(\mathrm{W} / \mathrm{m}^{2} / \mathrm{sr} / \mathrm{cm}^{-1}\right)$ and $\mathrm{m}$ is the cosine of the zenith angle associated with the direction of the radiation beam under consideration; $+m$ and $-m$ indicate upwelling and downwelling beams contributing respectively to the upward and the downward irradiances. The spectral integration is usually performed over the wavenumber domain $0-3000 \mathrm{~cm}^{-1}$, which encompass about $99.95 \%$ of the irradiance emitted by a blackbody at $300 \mathrm{~K}$. Thus, irradiances can be obtained through a spectral integration, followed (or preceded) by a hemispherical integration. Spectral radiances constitute solutions of the radiative transfer equation which in turn, under clear-sky conditions and throughout the terrestrial spectrum, can be written in the form:

$$
\pm \mu \frac{d L(v, \pm \mu, z)}{d z}=\alpha(v, z)[B(v, T(z))-L(v, \pm \mu, z)]
$$

where $a(u, z)$ is the volume absorption coefficient, and $\mathrm{B}(\mathrm{u}, \mathrm{T}(\mathrm{z}))$ is the blackbody spectral radiance given by the Planck function at the temperature T(z). Thus, downwelling (or upwelling) spectral radiances at a given altitude result from emission not counterbalanced by absorption of radiation above (or below) this level. Spectral radiances can be formally derived from the equation above through vertical integration (e.g., Liou, 1980, pp.22-23); they depend on direct atmospheric transmittances, which can be defined as:

$t(v, \mu, z)=\exp \left(-\int_{z}^{\infty} \alpha\left(v, z^{\prime}\right) d z^{\prime} / \mu\right)$

Further details on radiative transfer in planetary atmospheres may be found in some textbooks (e.g., Goody \& Yung, 1989; Liou, 1992).

The most straightforward, but most computer time consuming, technique for evaluating irradiances is to specify $\mathbf{a}(\mathbf{u}, \mathbf{z})$ at sufficiently small intervals $\left(10^{-4}\right.$ to $10^{-2}$ $\mathrm{cm}^{-1}$ ) and throughout the atmosphere. This is no small task because $\mathbf{a}(\mathbf{u}, \mathbf{z})$ depends on the locations, strengths, and shapes of the spectral lines throughout the spectrum. Because this technique involves summing the contributions of each spectral line, it is usually called the line-by-line technique (Ellingson et al., 1991). The time spent in such calculations is so substantial, even on current computers, that the line-by-line technique is usable, in practice, only for selected benchmark calculations (Schwarzkopf \& Fels, 1991). For the sake of information, the wavenumber 
domain 0-3000 $\mathrm{cm}^{-1}$ contains about 10,000 spectral lines associated with the water vapor, about 39,000 to the carbon dioxide, and about 160,000 to the ozone (Rothman et al., 1992).

The benchmark calculations chosen for comparison in this study were performed by other groups through the line-by-line technique, employing reference radiative transfer codes: (a) a version of Fast Atmospheric Signature Code (FASCOD2) (Clough et al., 1986), modified by S.A. Clough and collaborators at the Atmospheric and Environmental Research (AER), and (b) the National Oceanic and Atmospheric Administration (NOAA) Geophysical Fluid Dynamics Laboratory (GFDL) code (Schwarzkopf \& Fels, 1991). Longwave irradiances supplied by codes AER and GFDL agree very well, and the existing deviations can be satisfactorily understood (Bernstein et al., 1996). Results provided by the code AER have been selected as the closest reference currently available to the true atmosphere under realistic conditions (e.g., Baer et al., 1996).

\section{LONGWAVE SIMPLIFIED RADIATION CODES}

The line-by-line technique has been used not only in the preparation of benchmark calculations associated with prescribed atmospheric conditions, but also in the development of simplified radiation codes. The latter would provide suitable solutions for well-defined problems in radiative transfer, and their conception can be guided by a compromise previously defined between acceptable accuracy and low computational cost.

The use of general circulation models for numerical weather predictions and climate projections requires fast and relatively accurate radiation codes for obtaining irradiances integrated over the whole longwave (terrestrial) and shortwave (solar) domains. An example of such codes is the one proposed by Harshvardhan et al. (1987), included in the COLA general circulation model which runs daily at the CPTEC/INPE (Cachoeira Paulista, SP). In this code, longwave irradiances $\left(0-3000 \mathrm{~cm}^{-1}\right)$ are obtained by summing the contributions associated with ten spectral intervals. Under clear-sky atmospheric conditions, the contribution associated with a given spectral interval is estimated by taking into account the effects due to the emission / absorption by a single absorber only (water vapor, carbon dioxide, or ozone). Downward and upward irradiances at a given level are obtained directly in irradiance units, by combining the local emission with the transmitted fraction of the emission associated with other levels; in the case of upward irradiances, the surface at the ground is assumed a blackbody. Hemispherically- and spectrally- averaged values of direct transmittances $\mathbf{t}(\mathbf{u}, \mathbf{m}, \mathbf{z})$ are obtained through the procedures proposed by Chou (1984) for water vapor and by Chou \& Peng (1983) for carbon dioxide. The method of Rodgers (1968) is employed for estimating the emission / absorption effects due to ozone in the region 980-1100 $\mathrm{cm}^{-1}$ (wavelengths near $9.6 \mathrm{~mm}$ ).

The line-by-line technique has been employed also in the development of a second class of simplified radiation codes, whose accuracy and computational cost would be higher than those included in general circulation models. These codes would enable suitable solutions for a number of problems in atmospheric optics like the computation of direct transmittances under a low spectral resolution simulation $\left(20 \mathrm{~cm}^{-1}\right)$, the simulation of radiances measured onboard meteorological satellites, and the evaluation of solar diffuse radiation resulting from single scattering in the atmosphere. Such a class includes the Low Resolution Transmittance (LOWTRAN) codes, whose history has been recently compiled (Anderson et al., 1995). The latest version, named LOWTRAN-7 (Kneizys et al., 1988) and available ten years ago, constitutes even today the basic framework of the Moderate Resolution Transmittance (MODTRAN) codes (Kneizys et al., 1996). Under clearsky atmospheric conditions, the code LOWTRAN-7 provides relatively accurate radiance estimations throughout the longwave spectrum (Clough et al., 1989). In this code, a series of procedures successively proposed by Pierluissi et al. (1989) for water vapor, by Pierluissi \& Tsai (1987) for carbon dioxide, and by Pierluissi \& Maragoudakis (1986) for ozone are employed; in all cases, spectrally-averaged values of direct transmittances $t(u, m, z)$ are obtained from parameterizations derived from line-byline calculations.

A code based on LOWTRAN-7 was implemented at the IAG-USP as an instrument for analysis of atmospheric thermodynamic profiles resulting either from field campaigns or from mesoscale numerical modeling. A similar code was developed by Dutton (1993) and it has been employed as an element of quality control of longwave irradiance data at the World Radiation Monitoring Centre (Gilgen et al., 1995). The code developed at the IAG-USP provides irradiances from radiances previously computed by running the code LOWTRAN-7 under the atmospheric conditions of interest. These radiances are obtained for a number of incidence angles, selected for enabling irradiances through the first moment quadrature approach followed by Clough et al. (1992). Radiances corresponding to the longwave spectrum $\left(0-3000 \mathrm{~cm}^{-1}\right)$ are integrated in LOWTRAN-7 from spectral radiances previously obtained every $20 \mathrm{~cm}^{-1}$.

\section{WATER VAPOR CONTINUUM ABSORPTION}

The water vapor absorption is characterized by a very strong spectral dependence throughout well-defined regions of significant absorption (bands) situated between the near-infrared and the microwave wavelength domains, being that everyone of these regions is associated with the occurrence of hundreds / thousands of lines. A second 
structure, characterized by a relatively weak spectral dependence, has been recognized at least since the sixties (e.g., Bignell et al., 1963) from observations between successive bands. Despite of its relatively long history, the theory on the cause of this smoother (or continuum) structure is still a matter of controversy. As briefly recalled by Liou (1992, p. 36-37), "The attenuation due to the water vapor continuum remains a theoretical mystery. It has been suggested that the continuum results from the accumulated absorption of the distant wings of water vapor lines, principally in the far-infrared part of the spectrum (e.g., see Clough et al., 1989). This absorption is caused by the collision broadening between absorbing molecules $\left(\mathrm{H}_{2} \mathrm{O}\right.$ $\mathrm{H}_{2} \mathrm{O}$ ) and between absorbing and non-absorbing molecules $\left(\mathrm{H}_{2} \mathrm{O}-\mathrm{N}_{2}\right)$. There is evidence that contributions to continuous absorption may be caused by water dimer $\left(\mathrm{H}_{2} \mathrm{O}\right)_{2}$. However, this possibility has yet to be verified."

From a practical point of view, this continuum absorption can be primarily defined as the contribution to the molecular absorption that should be added to the lineby-line contribution for providing computed results consistent with the measurements (Clough et al., 1992). A number of studies has been conducted in estimating the influence of water vapor continuum absorption on shortwave (e.g., Arking, 1999) and on longwave irradiances (e.g., Schwarzkopf \& Ramaswamy, 1999), as well as in assessing the range of validity of the available parameterizations (e.g., Tobin et al., 1999). According to Ellingson et al. (1991), the inclusion of the effects due to the water vapor continuum absorption in radiative transfer calculations - either in reference codes or in simplified codes - follows basically one of two approaches.

The first one, proposed by Roberts et al. (1976) from measurements between 400 and $1200 \mathrm{~cm}^{-1}$, establishes that the contribution due to the continuum absorption at a given wavenumber is directly proportional to the water vapor partial pressure. Thus, such approach would allow satisfactory results in those parts of the atmosphere containing significant amounts of water vapor, that is throughout the lower troposphere. This approach (hereafter recalled as RSB, from Roberts-Selby-Biberman) is adopted in the reference code GFDL and in the simplified code CPTEC/COLA.

According to the second approach, proposed by Clough et al. (1989) and successively improved since then (Clough et al., 1992; Han et al., 1997), the contribution due to the continuum absorption at a given wavenumber is expressed by a sum of two terms, respectively proportional to the water vapor partial pressure ("self component") and to the dry air pressure ("foreign component"). The inclusion of the latter in radiative transfer calculations enables continuum absorption estimates throughout the entire spectrum, and increases the reliability of radiative heating / cooling rates under relatively dry atmospheric conditions (Ellingson et al., 1991). Continuum absorption estimates are performed in the codes AER and LOWTRAN-7 through the first version (labeled CKD0) of the procedure developed by Clough and his collaborators.

\section{RESULTS AND DISCUSSION}

Comparisons are performed under hypothetical atmospheric conditions, most of them prescribed in the scope of the program Intercomparison of Radiative Codes used in Climate Models (ICRCCM) - see Ellingson \& Fouquart (1991) for an overview. Such conditions include isothermal and realistic atmospheres. Table 1 presents in detail the cases taken into account. Case numbers follow those associated with the longwave clear-sky cases summarized in table 3 of Ellingson et al. (1991), except the cases labelled 25/1 and 33/1. These latter constitute modified cases for which a number of post-ICRCCM studies (Clough et al., 1992; Bernstein et al., 1996) have provided benchmark calculations. Tropical, Mid-Latitude Summer and Sub-Arctic Winter model atmospheres result from compilations published by McClatchey et al. (1972) from sounding data. In this study, these model atmospheres were taken into account exactly as displayed in table 5, 6, and 9 of Ellingson et al. (1991). A blackbody surface at the same temperature than the lowest atmospheric level is assumed. The last column in Tab. 1 shows the source of benchmark calculations employed for every case in this study.

The interest on different atmospheric conditions can be justified as follows. Isothermal conditions (cases 1, 5, 42, and 43) represent school cases, for which possible biases could be easily identified. Non-isothermal single-absorber conditions (cases 9, 19, 20, 23c, 25/1, and 33/1) enable the analysis of the different procedures conceived for computing emission / absorption effects under realistic air temperature profiles. The reliability of the procedures used in the codes IAG-USP and CPTEC/COLA for estimating the effects due to the water vapor absorption, particularly those usually referred as continuum absorption, can be discussed from a number of sensitivity tests (cases 42 and 43 under isothermal conditions, 19 and 20 under realistic conditions). Lastly, the overall reliability of both codes may be assessed by accounting the effects due to the emission / absorption by carbon dioxide, ozone, and water vapor, under conditions which could in principle to be found from soundings (cases 25, 27, and 33).

The reliability of the simplified radiation codes IAGUSP and CPTEC/COLA is analyzed in this study from comparisons between respective irradiance values at selected levels of the atmosphere only. Comparisons involving profiles of radiative cooling rates only (e.g.: Harshvardhan et al., 1987; Baer et al., 1996) may indicate the reliability of air temperature tendencies due to absorption / emission processes, but cannot identify possible biases on radiation budget estimates at the surface. The choice adopted in this study enables the identification of systematic errors on irradiances, which could be 
eventually counterbalanced in the calculation of heating rates.

Table 2 summarizes, case by case, benchmark calculations obtained with reference codes (AER and / or GFDL) and corresponding results provided by the simplified codes IAG-USP and CPTEC/COLA. Benchmark calculations were taken (a) from Table 1 of Bernstein et al. (1996), (b) from table 2 of Ridgway et al. (1991) and (c) from the public directory pub/ICRCCMradiative_fluxes/data, available through the FTP server cdiac.esd.ornl.gov of the Carbon Dioxide Information Analysis Center, Oak Ridge National Laboratory, supported by the United States Department of Energy. Except where noted, results corresponding to the code IAGUSP were obtained by applying the default procedure (CKD0) for estimating the effects due to the water vapor continuum absorption included in the radiative transfer code LOWTRAN-7. Except where noted, benchmark calculations and results provided by the codes IAG-USP and CPTEC/COLA correspond to the wavenumber domain $0-3000 \mathrm{~cm}^{-1}$. Results are discussed mainly by comparing downward irradiances at the surface level, whose values can be associated with the emitting ability of the entire atmosphere. The analysis of upward irradiances is more complicated because the ground emission constitutes a relatively strong boundary condition.

Benchmark calculations provided by reference codes GFDL and AER are compared under specific conditions, with water vapor only in the atmosphere (cases 19, 20 and 25/1). Discrepancies between downward irradiances at the surface obtained with GFDL and AER codes present essentially the same magnitude when the water vapor continuum absorption are neglected or included, and it can be partially explained by the coarser spectral sampling used in the GFDL code (Bernstein et al., 1996). Deviations between these reference codes fall below $4 \mathrm{~W} / \mathrm{m}^{2}$. Such order of magnitude was identified during the program ICRCCM, being since then recalled as motivation for accurate field validations like the Spectral Radiance Experiment (SPECTRE) (Ellingson \& Wiscombe, 1996).

Under isothermal atmospheric conditions (cases 1, 5, 42, and 43), upward irradiances assume a constant value between the surface and the top of the atmosphere once the radiation absorbed by each layer is re-emitted at the same temperature. The conception of the code IAG-USP was checked through the analysis of such kind of result. In the case of upward irradiances, the application of the threepoint Gauss quadrature proposed by Lacis \& Oinas (1991) - as suggested by Dutton (1993) - provided upward irradiances less accurate than those obtained by employing the first moment quadrature of Clough et al. (1992). The fact can be explained by the selection of incidence angles, once the influence of atmospheric refraction (intrinsically taken into account in LOWTRAN-7 results) increase with the zenith angle.

The reliability of the codes IAG-USP and CPTEC/ COLA for estimating the effects due to the emission / absorption by carbon dioxide may be analyzed under isothermal (cases 1 and 5) as well as under a realistic air temperature condition (case 9). Downward irradiance estimates provided by the code IAG-USP may be present important biases under cold conditions: about $+3 \mathrm{~W} / \mathrm{m}^{2}$ at the surface for case 1 , and more than $+1 \mathrm{~W} / \mathrm{m}^{2}$ at the tropopause for case 9 ; it can be partially explained by the fact that such cold conditions were not included in the lineby-line calculations performed by Pierluissi \& Tsai (1987) into the development of the procedure included in the code LOWTRAN-7 for obtaining spectrally-averaged direct transmittances associated with the carbon dioxide. Downward irradiances obtained with the code CPTEC/ COLA seems more accurate, although it seems convenient to recall that calculations performed with the GFDL reference code were employed during the development of the code proposed by Harshvardhan et al. (1987).

The effects due to the ozone (case 23c) are systematically underestimated by the code CPTEC/COLA, allowing weaker downward irradiances and stronger upward irradiances than those provided by reference codes. The occurrence of such a bias is coherent with the fact that Harshvardhan et al. (1987) neglected all absorption by ozone outside the $980-1100 \mathrm{~cm}^{-1}$ region in the development of that simplified code. The effects due to the emission / absorption by ozone are estimated over practically the entire terrestrial spectrum $\left(0-3260 \mathrm{~cm}^{-1}\right)$ in the code LOWTRAN7; therefore, these effects are intrinsically considered by the code IAG-USP. The fact would explain the good agreement between downward irradiances at the surface provided by the code IAG-USP and corresponding benchmark calculations. Nevertheless, such agreement is somewhat illusory, once noticeable biases can be verified for downward irradiances at the tropopause.

The reliability of the procedures used in codes IAGUSP and CPTEC/COLA for estimating the effects due to the water vapor line absorption - that is, without the continuum contribution - may be analyzed under a realistic (case 20) as well as under a isothermal atmospheric condition (case 43). Both simplified codes provide underestimated downward irradiances at the ground, sometimes by $10 \mathrm{~W} / \mathrm{m}^{2}$ or more. The origin of these biases remain unexplained and its magnitude enhance a wellknown point-of-view in the radiation community, in which water vapor absorption estimates provided by simplified radiation codes should be discarded if the continuum contribution was neglected.

The importance of the continuum absorption associated with the water vapor may be measured by comparing the benchmark calculations corresponding to the cases 19 and 20, provided by AER and GFDL reference codes. Once the contribution associated with the continuum absorption is additional to the line absorption, its inclusion enhances the emitting and the absorbing efficiencies of atmospheric layers, while reduces the respective direct transmittance. Thus, upward irradiances decrease while downward irradiances increase when the continuum 


\begin{tabular}{|c|c|c|c|c|c|}
\hline C a se & A tmosphere & $\mathrm{H}_{2} \mathrm{O}$ absorption & $\mathrm{CO}_{2}$ absorption & $\mathrm{O}_{3}$ absorption & Benchm ark calculations \\
\hline 1 & Is o the erm a l $\left(\begin{array}{llll}2 & 0 & 0 & \mathrm{~K}\end{array}\right)$ & $\mathrm{No}$ & 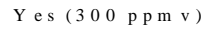 & $\mathrm{No}$ & G F D L \\
\hline 5 & Is o the rm a l $\left(\begin{array}{llll}3 & 0 & 0 & \mathrm{~K}\end{array}\right)$ & $\mathrm{No}$ & 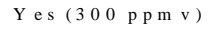 & $\mathrm{No}$ & G F D L \\
\hline 9 & M id-Latitude $S$ um mer & $\mathrm{No}$ & Yes $\left(\begin{array}{llll}3 & 0 & 0 & \mathrm{ppm} v\end{array}\right)$ & $\mathrm{No}$ & G F D L \\
\hline 19 & $M$ id - Latitude $S$ u m mer & Yes, with continu u $m$ & $\mathrm{No}$ & $\mathrm{No}$ & G F D L, A E R \\
\hline 20 & $M$ id - Latitude $S$ um mer & Yes, w ithout continu um & $\mathrm{No}$ & $\mathrm{No}$ & G F D L, A E R \\
\hline $23 \mathrm{c}$ & M id - Latitude $S$ um mer & $\mathrm{No}$ & $\mathrm{No}$ & $\begin{array}{l}\text { Yes, with } 9.6 \text { and } \\
14 \mu \mathrm{m} \mathrm{bands}\end{array}$ & G F D L \\
\hline 25 & Tropical & Yes, with continu um & Yes $\left(\begin{array}{llll}0 & 0 & 0 & \mathrm{ppm} v\end{array}\right)$ & $\begin{array}{l}\text { Yes, with } 9.6 \text { and } \\
14 \mu \mathrm{m} \mathrm{bands}\end{array}$ & G F D L \\
\hline $25 / 1$ & Tropical & Yes, with continu um & $\mathrm{No}$ & $\mathrm{No}$ & A E R \\
\hline 27 & M id-Latitude Sum mer & Yes, with continu um & 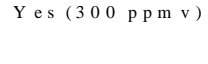 & $\begin{array}{l}\text { Yes, w ith } 9.6 \text { and } \\
14 \mu \mathrm{m} \mathrm{bands}\end{array}$ & G F D L \\
\hline 33 & $\mathrm{Sub}-\mathrm{Arctic} W$ inter & Yes, w ith continu um & Yes $\left(\begin{array}{llll}3 & 0 & 0 & \mathrm{ppm} v\end{array}\right)$ & $\begin{array}{l}\text { Yes, with } 9.6 \text { and } \\
14 \mu \mathrm{m} \mathrm{bands}\end{array}$ & G F D L \\
\hline $33 / 1$ & $\mathrm{Sub}-\mathrm{Arctic} W$ inter & Yes, with continu u & $\mathrm{No}$ & $\mathrm{No}$ & A E R \\
\hline 42 & Is o the rm a l $\left(\begin{array}{llll}2 & 0 & 0 & \mathrm{~K}\end{array}\right)$ & 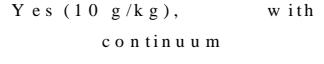 & $\mathrm{No}$ & $\mathrm{No}$ & G F D L \\
\hline 43 & Is o the rm a l $\left(\begin{array}{llll}3 & 0 & 0 & \mathrm{~K}\end{array}\right)$ & 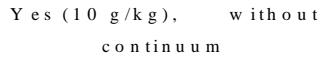 & $\mathrm{No}$ & $\mathrm{No}$ & G F D L \\
\hline
\end{tabular}

Table 1- Summary of test cases and sources of benchmark calculations taken into account in this study.

Tabela 1- Resumo das condições de teste e das fontes de resultados de referência levadas em conta neste estudo.

absorption is taken into account. Results provided by both reference codes show that, in the case of downward irradiances at the surface, such an effect reaches more than $60 \mathrm{~W} / \mathrm{m}^{2}$ under Mid-Latitude Summer atmospheric conditions. The meteorological consequences of such absorption are noticeable, and most of them are recognized at least since the seventies (e.g., Bignell, 1970).

This same comparison (cases 19 and 20) shows that the inclusion of water vapor continuum absorption seems unable to affect the downward irradiances at the tropopause provided by the GFDL code. The result can be directly associated with the differences existing between the approaches followed in the reference codes AER and GFDL for estimating the effects due to the continuum absorption; while in the code AER both components of the continuum (self and foreign, related respectively to the water vapor partial pressure and to the dry air pressure) are taken into account, only the first one is estimated by the RSB parameterization involved in the code GFDL. These differences can be appreciated from comparisons performed with a same procedure for estimating water vapor line absorption effects. In this goal, some sensitivity tests (cases 19, 25/1, and 33/1) were conducted with the code IAG-USP. The application of the parameterization RSB underestimates downward irradiances at the surface when compared with respective results obtained with the default procedure CKD0 included in the code LOWTRAN7. Such a bias decreases with the integrated content of water vapor in the atmosphere, from $-6.8 \mathrm{~W} / \mathrm{m}^{2}$ under Sub-Arctic Winter conditions $\left(8.6 \mathrm{~kg} / \mathrm{m}^{2}\right)$ to $-1.6 \mathrm{~W} / \mathrm{m}^{2}$ under Tropical atmospheric conditions $\left(41.4 \mathrm{~kg} / \mathrm{m}^{2}\right.$ of water vapor). The fact is coherent with the unsuitability of the parameterization RSB for estimating the water vapor continuum effects under relatively dry atmospheric conditions, as mentioned above (see the previous section).

According to Ellingson et al. (1991), the inclusion of the water vapor continuum absorption can mask differences existing between results provided by radiation codes. The fact can be appreciated for cases 19 and 20 in terms of downward irradiances at the surface. The difference between results obtained with the reference codes AER and GFDL increases with the inclusion of water vapor continuum absorption $\left(+2.2 \mathrm{~W} / \mathrm{m}^{2}\right.$ without it, +3.5 $\mathrm{W} / \mathrm{m}^{2}$ with it, first code minus second code), and a possible reason for this is that the RSB approach included in the code GFDL underestimates the water vapor continuum absorption, and therefore the atmospheric efficiency for emitting radiation. On the other hand, differences between results provided by reference codes (AER, GFDL) and simplified codes (IAG-USP, CPTEC/COLA) decrease with the inclusion of water vapor continuum absorption: it can be observed between the codes AER and IAG-USP $(+11.2$ $\mathrm{W} / \mathrm{m}^{2}$ without it, $+6.1 \mathrm{~W} / \mathrm{m}^{2}$ with the procedure CKD0), as well as between the codes GFDL and CPTEC/COLA $\left(+7.2 \mathrm{~W} / \mathrm{m}^{2}\right.$ without it, $+1.6 \mathrm{~W} / \mathrm{m}^{2}$ with the procedure $\left.\mathrm{RSB}\right)$. Such second class of differences, which decrease with the 
inclusion of the continuum absorption, can be attributed to the fact that some parameters involved in simplified codes are tuned in order to match results provided by reference codes.

The overall reliability of the codes IAG-USP and CPTEC/COLA may be assessed by accounting the effects due to the emission / absorption by carbon dioxide, ozone and water vapor, under conditions which could in principle to be found from meteorological soundings (cases 25, 27, and 33). Under such conditions, emission / absorption by water vapor is partially masked by the presence of carbon dioxide and ozone, and therefore the results cannot be directly associated with the integrated content of water vapor. Downward irradiances may be underestimated or overestimated by the code IAG-USP, depending on the model atmosphere. Under relatively dry, cold conditions (Sub-Arctic Winter model), such a bias reaches $+10 \mathrm{~W} / \mathrm{m}^{2}$ at the surface and $+3.1 \mathrm{~W} / \mathrm{m}^{2}$ at the tropopause; under relatively warm, wet conditions (Tropical model), it reaches $-5.9 \mathrm{~W} / \mathrm{m}^{2}$ at the surface and $+0.2 \mathrm{~W} / \mathrm{m}^{2}$ at the tropopause. It must be noted that these figures are evaluated from benchmark calculations provided by the reference code GFDL, which includes an approach unable for accurately estimating the water vapor continuum absorption effects under relatively dry conditions (see above). On the other hand, downward irradiances at the surface are systematically underestimated by the code CPTEC/COLA, such a bias reaching $-3.3,-4.5$, and $-3.0 \mathrm{~W} / \mathrm{m}^{2}$ respectively under Sub-Arctic Winter, Mid-Latitude Summer and Tropical conditions.

Climate modelers have interest not only on the downward irradiance at the surface level (by its implications on the availability of energy at the interface between the ground and the atmosphere, and therefore on the surface temperature) but also on the upward irradiance at the top of the atmosphere, which counterbalances the shortwave (solar) radiant energy absorbed by the planet. However, as noted before, the ground emission constitutes a relatively strong boundary condition for upward irradiances, turning more difficult the analysis of the reliability of simplified codes. Results presented in Tab. 2 show that the biases associated with the upward irradiance estimates at the top of the atmosphere provided by the code IAG-USP reach -6.2 and $-9.5 \mathrm{~W} / \mathrm{m}^{2}$ respectively under Sub-Arctic Winter and Tropical atmospheric conditions (see cases 25 and 33); in the case of the code CPTEC/ COLA, these respective biases reach only -0.3 and +0.9 $\mathrm{W} / \mathrm{m}^{2}$. Such results would indicate that the procedures included in the code developed by Harshvardhan et al. (1987) enable very good estimates of the planet emission, either under dry and cold conditions or under moist and warm conditions. Nevertheless, it must be recalled that the development of this simplified code was based upon lineby-line calculations performed by the same reference code (GFDL) which provided the benchmark results corresponding to the cases 25 and 33 shown in our Tab. 2 .

The results obtained with the codes IAG-USP and
CPTEC/COLA can be easily inserted in the ICRCCM context. Excepting one hypothetical condition (case 43: isothermal atmosphere at $300 \mathrm{~K}$, only water vapor), the agreement between results provided by these codes and respective benchmark calculations is better than $12 \mathrm{~W} / \mathrm{m} 2$ for downward irradiances at the surface as well as for net irradiances $(F Y ́-F ß)$ at the tropopause. Thus, following the criteria adopted by Ellingson et al. (1991) for ranking simplified radiation codes, both would be labelled "category 1 models", those which "appear to be reasonably performing the bulk calculations of tropospheric fluxes and heating rates" according to those authors. Such a label was previously attributed to the code developed by Harshvardhan et al. (1987) by Ellingson et al. themselves; in other words, our study can be recognized as consistent in respect to the ICRCCM exercises.

\section{RECOMMENDATION}

Comparisons as presented above enable the assessment of the relative accuracy associated with simplified radiation codes, in the sense that their results are compared with those provided by reference radiation codes whose conception was based upon a smaller number of approximations. Given the absence of calculations which could be considered "exact", the assessment of the absolute accuracy associated with simplified codes (and that one related to reference codes too) seems to depend on the analysis of careful measurements of irradiances at the surface and throughout the atmosphere, together with ancillary techniques for sensing of vertical profiles of air temperature and absorber concentrations. This is one of the motivations of two significant programs under development at present, namely: (a) the Atmospheric Radiation Measurement (ARM), supported by the U.S. Department of Energy (Stokes \& Schwartz, 1994), and (b) the Baseline Surface Radiation Network (BSRN), proposed by the Joint Scientific Committee for the World Climate Research Program (Gilgen et al., 1995; Ohmura et al., 1998). Following such international efforts and in order to validate longwave radiation codes employed in tropical regions, the design of field campaigns and / or the beginning of routine measurements involving pyrgeometers accurately calibrated should be taken as a major task by the Brazilian radiation community.

Since the submission of the first version of the present article and in the scope of two main research projects involving a number of Brazilian institutions, the first named author has performed measurements with pyrgeometers during meteorological field experiments conducted in Rondônia (RO) and at São Paulo (SP). The analysis of both data sets is in progress, involving the field validation of one reference code and of at least two simplified radiation codes. 


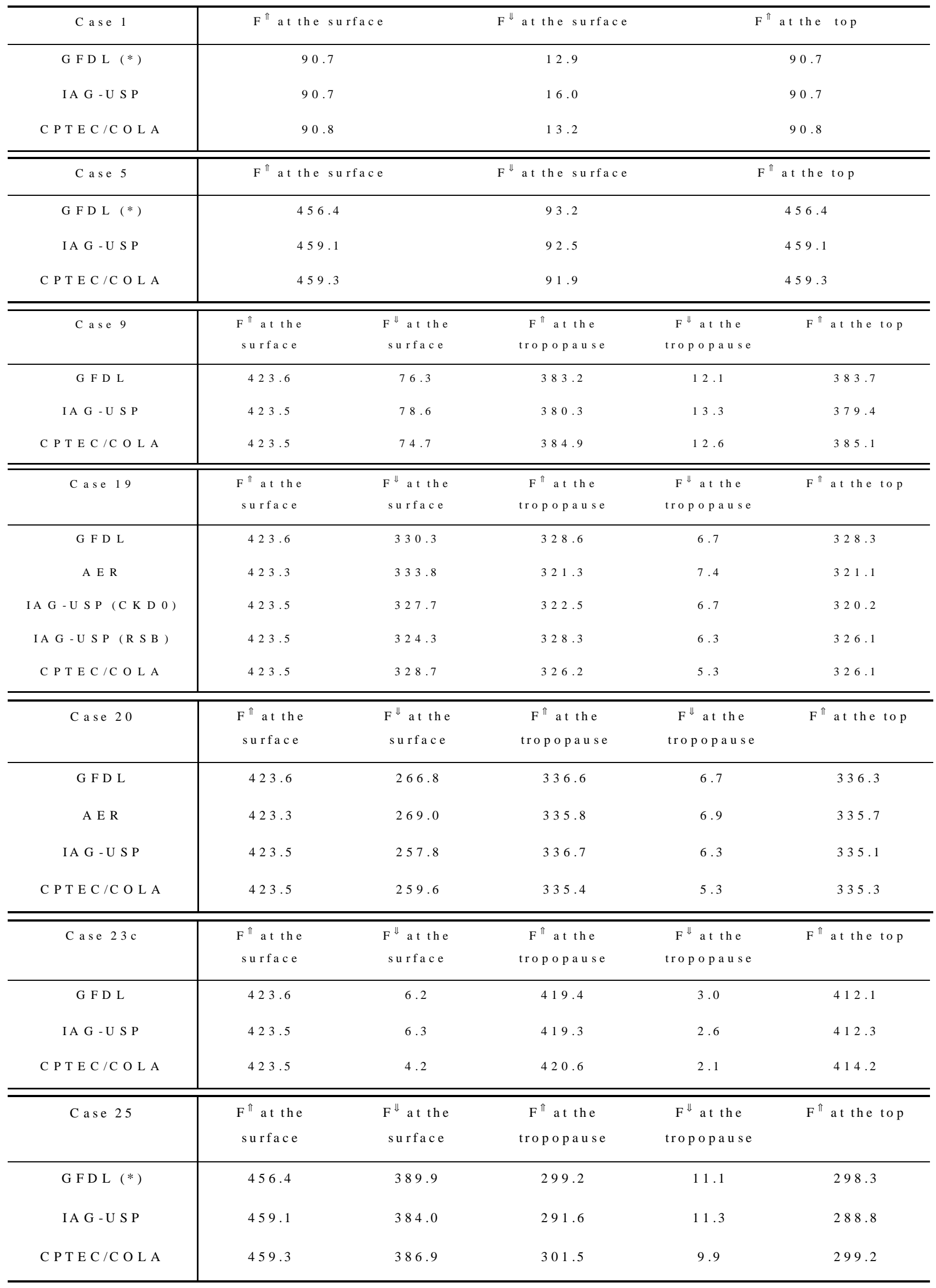




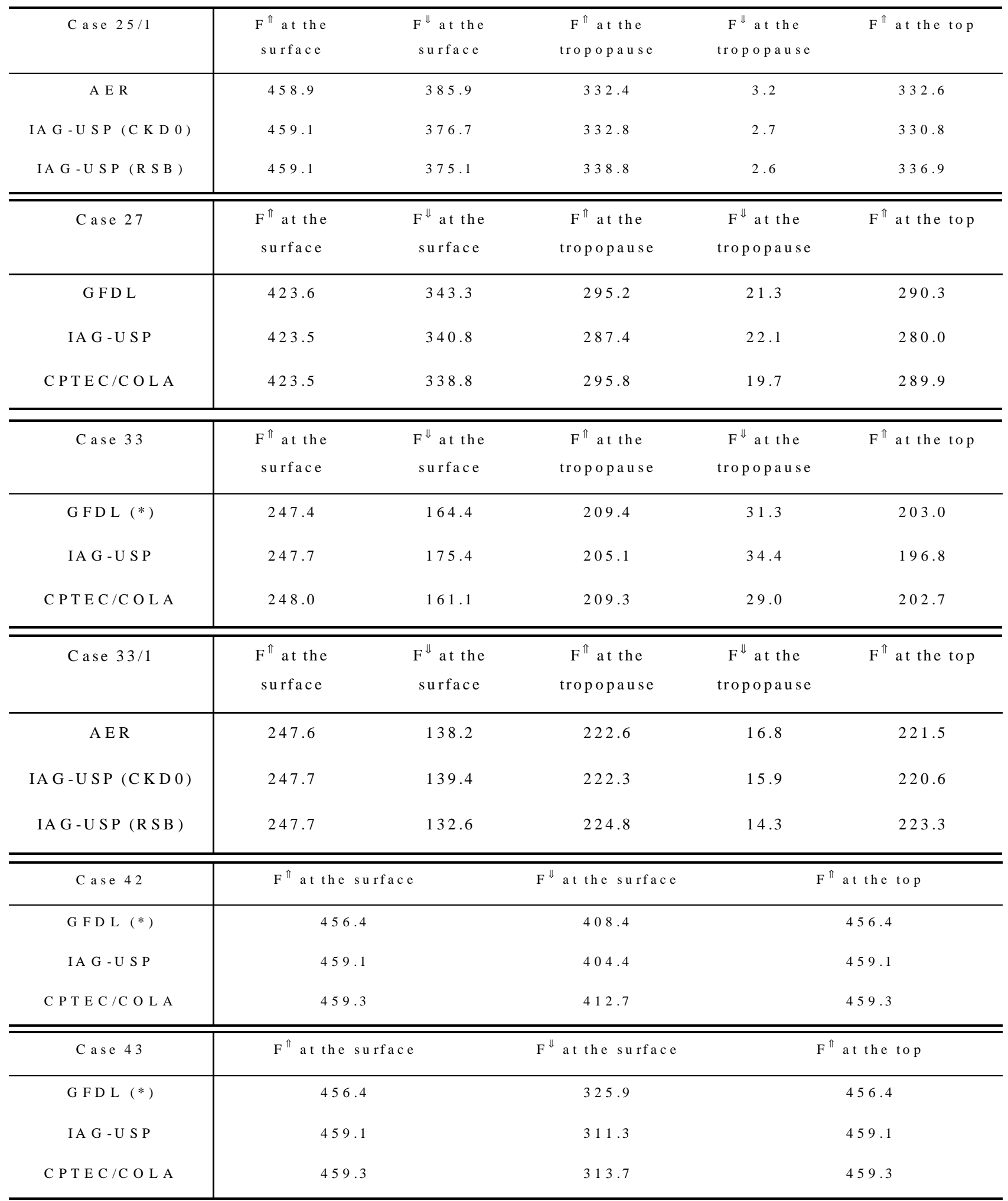

(*) $0-2200 \mathrm{~cm}^{-1}$

Table 2. Irradiances (W/m2) obtained through benchmark calculations (GFDL, AER) and provided by simplified codes (IAG-USP, CPTEC/COLA) under selected conditions (see Tab. 1). Except where noted, results labeled IAG-USP were obtained by applying the default procedure (CKD0) included in the code LOWTRAN-7 for estimating the effects due to the water vapor continuum absorption.

Tabela 2- Irradiâncias (W/m2) obtidas com códigos radiativos de referência (GFDL, AER) e dos códigos simplificados IAG-USP e CPTEC/COLA para as condições estabelecidas na Tab. 1. A menos que seja dito o contrário, resultados fornecidos pelo código IAG-USP foram obtidos aplicandose o procedimento CKDO incluído no código LOWTRAN-7 para estimativa dos efeitos da absorção continuum associada ao vapor d'água. 


\section{ACKNOWLEDGMENTS}

The authors are sincerely indebted to P.L. da Silva Dias (Departamento de Ciências Atmosféricas, IAG-USP), to J.C. Ceballos (Centro de Previsão de Tempo e Estudos Climáticos, CPTEC/INPE) and to E.P. de Souza (Departamento de Ciências Atmosféricas, Universidade Federal da Paraíba) for helpful discussions. Deep acknowledgments are addressed to an anonymous reviewer for numerous comments on the manuscript, as well as to everyone who in past contributed to the ICRCCM database available through the FTP server cdiac.esd.ornl.gov of the Carbon Dioxide Information Analysis Center, Oak Ridge National Laboratory, supported by the U.S. Department of Energy. This study was partially supported by CNPq through a M.Sc. fellowship to one of the authors (P.A.F. Kuhn).

\section{REFERENCES}

ANDERSON, G.P., WANG, J., HOKE, M.L., KNEIZYS, F.X., CHETWYND, J.H., ROTHMAN, L.S., KIMBALL, L.M., McCLATCHEY, R.A., SHETTLE, E.P., CLOUGH, S.A., GALLERY, W.O., ABREU, L.W. \& SELBY, J.E.A. - 1995 History of one family of atmospheric radiative transfer codes. In Passive Infrared Remote Sensing of Clouds and the Atmosphere II (D.K. Lynch, Ed.), SPIE 2309: 170-183.

ARKING, A. - 1999 - Bringing climate models into agreement with observations of atmospheric absorption. Journal of Climate, 12(6): 1589-1600.

BAER, F., ARSKY, N., CHARNEY，J.J. \& ELLINGSON, R. - 1996 - Intercomparison of heating rates generated by global climate model longwave radiation codes. Journal of Geophysical Research, 101(D21): 26589-26603.

BERNSTEIN, L.S., BERK, A., ACHARYA, P.K., ROBERTSON, D.C., ANDERSON, G.P., CHETWYND, J.H. \& KIMBALL, L.M. - 1996 Very narrow band model calculations of atmospheric fluxes and cooling rates. Journal of the Atmospheric Sciences, 53(20): 2887-2904.

BIGNELL, K.J. - 1970 - The water-vapour infra-red continuum. Quarterly Journal of the Royal Meteorological Society, 96: 390-403.

BIGNELL, K.J., SAIEDY, F. \& SHEPPARD, P.A. 1963 - On the atmospheric infrared continuum. Journal of the Optical Society of America, 53: 466479.

BRIEGLEB, B.P. - 1992 - Longwave band model for thermal radiation in climate studies. Journal of Geophysical Research, 97(D11): 11475-11485.

CHOU, M.-D. - 1984 - Broadband water vapor transmission functions for atmospheric IR flux computations. Journal of the Atmospheric Sciences,
41(10): 1775-1778.

CHOU, M.-D. \& PENG, L. - 1983 - A parameterization of the absorption in the $15 \mathrm{~mm} \mathrm{CO} 2$ spectral region with application to climate sensitivity studies. Journal of the Atmospheric Sciences, 40: 2183-2192.

CLOUGH, S.A., KNEIZYS, F.X., SHETTLE, E.P. \& ANDERSON, G.P. - 1986 - Atmospheric radiance and transmittance: FASCOD2. In Extended Abstracts of Sixth Conference on Atmospheric Radiation, pp.141-144, American Meteorological Society, Williamsburg, VA.,USA.

CLOUGH, S.A., KNEIZYS, F.X. \& DAVIES, R.W. 1989 - Line shape and the water vapor continuum. Atmospheric Research, 23: 229-241.

CLOUGH, S.A., IACONO, M.J. \& MONCET, J.L. 1992 - Line-by-line calculations of atmospheric fluxes and cooling rates: application to water vapor. Journal of Geophysical Research, 97(D14): 15761-15785.

DUTTON, E.G. - 1993 - An extended comparison between LOWTRAN-7 computed and observed broadband thermal irradiances: global extreme and intermediate surface conditions. Journal of Atmospheric and Oceanic Technology, 10: 326-336.

ELLINGSON, R.G. \& FOUQUART, Y. - 1991 - The Intercomparison of Radiation Codes used in Climate Models: an overview. Journal of Geophysical Research, 96(D5): 8925-8927.

ELLINGSON, R.G. \& WISCOMBE, W.J. - 1996 - The Spectral Radiance Experiment (SPECTRE): project description and sample results. Bulletin of the American Meteorological Society, 77(9): 1967-1985.

ELLINGSON, R.G., ELLIS, J. \& FELS, S. - 1991 The Intercomparison of Radiation Codes used in Climate Models: long wave results. Journal of Geophysical Research, 96(D5): 8929-8953.

GILGEN, H., WHITLOCK, C.H., KOCH, F., MÜLLER, G., OHMURA, A., STEIGER, D. \& WHEELER, R. - 1995 - Technical Plan for BSRN (Baseline Surface Radiation Network) Data Management. World Radiation Monitoring Centre (WRMC), Technical Report 1 (Version 2.1, January 1995). Publ. WMO/TD No.443, 57pp.

GOODY, R.M. \& Y.L. YUNG - 1989 - "Atmospheric Radiation - Theoretical Basis (Second Edition)". Oxford University Press, New York, 519pp.

HAN, Y., SHAW, J.A., CHURNSIDE, J.H., BROWN, P.D. \& CLOUGH, S.A. - 1997 - Infrared spectral radiance measurements in the tropical Pacific atmosphere. Journal of Geophysical Research, 102(D4): 4353-4356.

HARSHVARDHAN, DAVIES, R., RANDALL, D.A. \& CORSETTI, T.G. - 1987 - A fast radiation parameterization for atmospheric circulation models. Journal of Geophysical Research, 92(D1): 1009-1016.

KNEIZYS, F.X., SHETTLE, E.P., ABREU, L.W., CHETWYND, J.H., ANDERSON, G.P., 
GALLERY, W.O., SELBY, J.E.A. \& CLOUGH, S.A. - 1988 - Users Guide to LOWTRAN-7. Environmental Research Papers, No. 1010, Publ. AFGL-TR-88-0177, 137pp., Air Force Geophys. Lab., Hanscom.

KNEIZYS, F.X., ABREU, L.W., ANDERSON, G.P., CHETWYND, J.H., SHETTLE, E.P., BERK, A., BERNSTEIN, L.S., ROBERTSON, D.C., ACHARYA, P., ROTHMAN, L.S., SELBY, J.E.A., GALLERY, W.O. \& CLOUGH, S.A. - 1996 - The MODTRAN 2/3 Report and LOWTRAN-7 Model. Report prepared by Ontar Corporation, for Phillips Laboratory, Geophysics Directorate (see the public file ftp: // amber.plh.af.mil / pub / chet / modtranreport / modrept.ps).

KUHN, P.A.F. - 1997 - Avaliação do Balanço de Radiação de Onda Longa na Atmosfera. Dissertação de Mestrado, Instituto Astronômico e Geofísico da Universidade de São Paulo, 78pp.

LACIS, A.A. \& OINAS, V. - 1991 - A description of the correlated k-distribution method for modeling nongray gaseous absorption, thermal emission, and multiple scattering in vertically inhomogeneous atmospheres. Journal of Geophysical Research, 96(D5): 9027-9063.

LIOU, K.-N. - 1980 - "An Introduction to Atmospheric Radiation". Academic Press, New York, 392pp.

LIOU, K.-N. - 1992 - "Radiation and Cloud Processes in the Atmosphere: Theory, Observation, and Modeling". Oxford University Press, New York, 487pp.

MCCLATCHEY, R.A., FENN, R.W., SELBY, J.E.A., VOLZ, F.E. \& GARING, J.S. - 1972 - Optical Properties of the Atmosphere (Third Edition). Publ. AFCRL-72-0497, 108pp., Air Force Cambridge Res. Lab., Hanscom.

OHMURA, A., DUTTON, E.G., FORGAN, B., FROHLICH, C., GILGEN, H., HEGNER, H., HEIMO, A., KONIG-LANGLO, G., McARTHUR, B., MULLER, G., PHILIPONA, R., PINKER, R., WHITLOCK, C.H., DEHNE, K. \& WILD, M. 1998 - Baseline Surface Radiation Network (BSRN/ WCRP): new precision radiometry for climate research. Bulletin of the American Meteorological Society, 79(10): 2115-2136.

PIERLUISSI, J.H. \& MARAGOUDAKIS, C.E. - 1986 - Molecular Transmission Band Models for LOWTRAN. Publ. AFGL-TR-86-0272, Air Force Geophys. Lab., Hanscom.

PIERLUISSI, J.H. \& TSAI, C.-M. - 1987 - New LOWTRAN models for the uniformly mixed gases. Applied Optics, 26(4): 616-618.

PIERLUISSI, J.H., MARAGOUDAKIS, C.E. \& TEHRANI-MOVAHED, R. - 1989 - New LOWTRAN band models for water vapor. Applied Optics, 28(18): 3792-3795.
RIDGWAY, W.L., HARSHVARDHAN \& ARKING, A. - 1991 - Computation of atmospheric cooling rates by exact and approximate methods. Journal of Geophysical Research, 96(D5): 8969-8984.

ROBERTS, R.E., SELBY, J.E.A. \& BIBERMAN, M. 1976 - Infrared continuum absorption by atmospheric water vapor in the $8-12 \mathrm{~mm}$ window. Applied Optics, 15(9): 2085-2090.

RODGERS, C.D. - 1968 - Some extensions and applications of the new random model for molecular band transmission. Quarterly Journal of the Royal Meteorological Society, 94: 99-102.

ROTHMAN, L.S., R.R. GAMACHE, R.H. TIPPING, C.P. RINSLAND, M.A.H. SMITH, D.C. BENNER, V.M. DEVI, J.-M. FLAUD, C. CAMY-PEYRET, A. PERRIN, A. GOLDMAN, S.T. MASSIE, L.R. BROWN \& R.A. TOTH - 1992 - The HITRAN molecular database: editions of 1991 and 1992. Journal of Quantitative Spectroscopy and Radiative Transfer, 48(5/6): 469-507.

SATO, N., SELLERS, P.J., RANDALL, D.A., SCHNEIDER, E.K., SHUKLA, J., KINTER III, J.L., HOU, Y.-T. \& ALBERTAZZI, E. - 1989 Effects of implementing the Simple Biosphere Model in a general circulation model. Journal of the Atmospheric Sciences, 46(18): 2757-2782.

SCHWARZKOPF, M.D. \& FELS, S.B. - 1991 - The simplified exchange method revisited: an accurate, rapid method for computation of infrared cooling rates and fluxes. Journal of Geophysical Research, 96(D5): 9075-9096.

SCHWARZKOPF, M.D. \& RAMASWAMY, V. - 1999 - Radiative effects of $\mathrm{CH} 4, \mathrm{~N} 2 \mathrm{O}$, halocarbons and the foreign-broadened $\mathrm{H} 2 \mathrm{O}$ continuum: A GCM experiment. Journal of Geophysical Research, 104(D8): 9467-9488.

STEPHENS, G.L. - 1984 - The parameterization of radiation for numerical weather prediction and climate models. Monthly Weather Review, 112: 826-867.

STOKES, G.M. \& SCHWARTZ, S.E. - 1994 - The Atmospheric Radiation Measurement (ARM) Program: programmatic background and design of the cloud and radiation test bed. Bulletin of the American Meteorological Society, 75(7): 1201-1221.

TOBIN D.C., BEST, F.A., BROWN, P.D., CLOUGH, S.A., DEDECKER, R.G., ELLINGSON, R.G., GARCIA, R.K., HOWELL, H.B., KNUTESON, R.O., MLAWER, E.J., REVERCOMB, H.E., SHORT, J.F., VAN DELST, P.F.W. \& WALDEN, V.P. - 1999 - Downwelling spectral radiance observations at the SHEBA ice station: water vapor continuum measurements from 17 to $26 \mathrm{~mm}$. Journal of Geophysical Research, 104(D2): 2081-2092. 


\section{UMA COMPARAÇÃO ENTRE CÓDIGOS RADIATIVOS DE ONDA LONGA}

A acurácia de dois algoritmos computacionais (códigos) simplificados para avaliação das componentes do balanço de radiação terrestre (radiação de onda longa), eficientes sob o ponto de vista computacional, é analisada neste estudo a partir de comparações envolvendo cálculos de referência sob condições atmosféricas previamente estabelecidas. Ambos os códigos foram concebidos a partir de aproximações sobre a transferência de radiação de onda longa na atmosfera, efetuadas no intuito de se obter resultados satisfatórios com baixo custo computacional. O primeiro deles foi desenvolvido no Instituto Astronômico e Geofísico da Universidade de São Paulo (IAG-USP; São Paulo, SP), fornecendo irradiâncias ao longo da atmosfera a partir das radiâncias integradas sobre todo o espectro terrestre e previamente calculadas pela versão 7 do código de transferência radiativa Low Resolution Transmittance, LOWTRAN-7 (Kneizys et al., 1988). Um código similar ao desenvolvido no IAG-USP foi proposto por Dutton (1993) e tem sido empregado no World Radiation Monitoring Centre como elemento de controle de qualidade para observações efetuadas com pirgeômetros (Gilgen et al., 1995). O segundo código foi desenvolvido por Harshvardhan et al. (1987) e incluído no modelo de circulação geral do Center for Ocean-Land-Atmosphere Studies (COLA; USA), que tem sido empregado no Centro de Previsão do Tempo e Estudos Climáticos do Instituto Nacional de Pesquisas Espaciais (CPTEC/INPE; Cachoeira Paulista, SP).

Resultados obtidos com ambos os códigos simplificados são comparados com cálculos de referência efetuados respeitando-se a influência das dezenas de milhares de linhas de absorção associadas aos três compostos moleculares mais relevantes à transferência de radiação de onda longa na atmosfera (vapor d'água, dióxido de carbono, e ozônio). Todas as comparações foram efetuadas para uma série de condições atmosféricas hipotéticas, sugeridas no âmbito do programa ICRCCM (Intercomparison of Radiative Codes used in Climate Models, Ellingson \& Fouquart, 1991). Estas condições hipotéticas incluem atmosferas isotérmicas e realistas (quanto a perfis de temperatura $\mathrm{e}$ de umidade do ar). A acurácia dos resultados fornecidos pelos códigos IAG-USP e CPTEC/COLA é avaliada comparando-se sobretudo irradiâncias descendentes à superfície do solo, cujos valores podem ser associados ao resultado final dos processos de emissão, de absorção e de re-emissão de radiação de onda longa pela atmosfera. As comparações efetuadas incluem somente condições atmosféricas associadas a "céu limpo" (sem aerossol) e a "céu aberto" (sem nuvens). Muito embora os efeitos devidos à cobertura de nuvens sobre o balanço de radiação terrestre sejam qualitativamente bem conhecidos, a avaliação da acurácia com a qual estes efeitos são quantificados em algoritmos computacionais constitui uma tarefa formidável e ainda fora de nossas possibilidades, dada a quase ausência de cálculos de referência bem documentados.

Os resultados fornecidos pelos códigos IAG-USP e CPTEC/COLA são comparados com três conjuntos de cálculos de referência previamente publicados. O acordo entre estes últimos pode ser considerado satisfatório, com discrepâncias inferiores a $4 \mathrm{~W} / \mathrm{m}^{2}$. Os efeitos associados ao dióxido de carbono são bem reproduzidos pelo código CPTEC/COLA e, a menos de condições atmosféricas relativamente frias, também pelo código desenvolvido no IAG-USP; a exceção teria origem no desenvolvimento da parametrização incluída no código LOWTRAN-7 para avaliação de valores médios espectrais da transmitância direta associada ao dióxido de carbono. Os efeitos associados ao ozônio são subestimados por ambos os códigos mas sobretudo pelo CPTEC/COLA, que não inclui linhas de absorção situadas fora da região $980-1100 \mathrm{~cm}^{-1}$. Testes de sensibilidade realizados sobre os efeitos da absorção continuum associada ao vapor d'água mostram que estes efeitos podem ser bem avaliados desde que sejam levadas em conta ambas as componentes desta absorção, ou seja, tanto a componente diretamente proporcional à pressão parcial do vapor d'água quanto àquela dependente da pressão total ambiente. Sob condições atmosféricas realistas, ambos os códigos considerados, e sobretudo aquele empregado no CPTEC/INPE, podem subestimar a irradiância descendente à superfície.

Comparações como as efetuadas acima permitem que se discuta apenas a acurácia relativa de algoritmos computacionais frente a cálculos teóricos cuja realização envolveu um número menor de aproximações. Estudos futuros devem avaliar a acurácia absoluta destes (e de outros) códigos, considerando a disponibilidade de medições da irradiância descendente à superfície mediante o emprego de pirgeômetros bem calibrados num sítio onde sejam efetuadas sondagens atmosféricas capazes de fornecer os perfis verticais de temperatura do ar e de concentração dos principais absorvedores. Seguindo-se uma linha de investigação complementar às análises aqui efetuadas, estudos futuros devem também se dedicar à avaliação da acurácia com a qual os efeitos devidos à cobertura de nuvens sobre o balanço de radiação terrestre são quantificados em códigos radiativos simplificados, dada a magnitude destes efeitos na definição do tempo e do clima. 